\title{
Kerkorde en ekumene. Die Nederduitse Gereformeerde Kerk in die jare 1962-2015
}

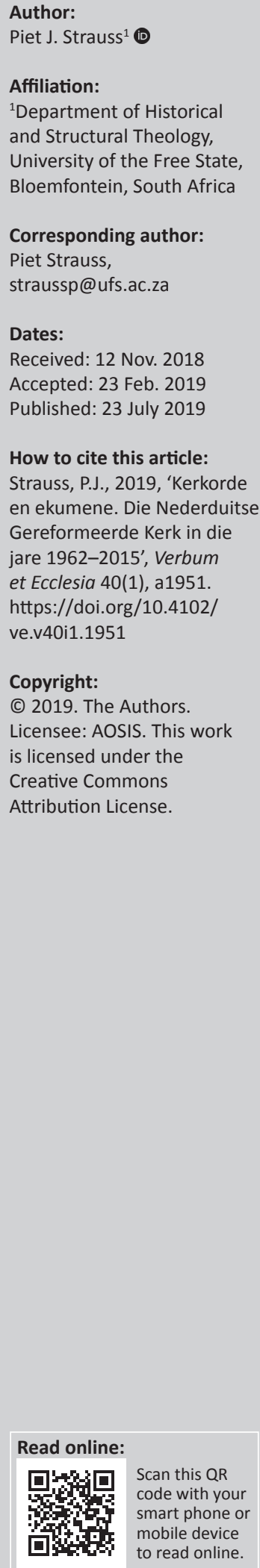

Church order and ecumenism: The Dutch Reformed Church in 1962-2015. The church order accepted by the first General Synod of the Dutch Reformed Church (DRC), the church order or DRC-CO of 1962, showed a preference for ecumenism with reformed churches. However, the term 'correspondence' with which it described the closest possible ties with a reformed church, was not explicit in the details of these ties. When the DRC broke its ties with the Reformed Churches in the Netherlands in 1976, the former could not explain in practical detail what had happened. The Netherlands church was the last church abroad with which the DRC had close ties. After this, the DRC were questioned more and more and became isolated from other churches outside South Africa because of, as it was called, its theological and moral support of apartheid. Changes within the DRC itself and in South Africa on apartheid in the years 1986-1994 also changed all this. The DRC was again accepted in church circles and became engaged in more ecumenical ties on a multi- as well as bilateral level than ever before.

Intradisciplinary/interdisciplinary implications: This article is of a church-political nature, which helps the church in formulating a church order. It combines church history with church polity and uses it for an ecumenical purpose. Ecumenics concentrates on the relations between churches as a theological discipline. The history of the ecumenics of the Dutch Reformed Church, however, is also connected to its history as a church in the history of South Africa as a country.

Keywords: ecumenical ties; church order; ecumenism aims; relations between churches; Dutch Reformed Church; Reformed Churches in the Netherlands; new spirit/drive; agreement on confessions; main lines of church government.

\section{Inleiding en probleem}

Navorsing dui daarop dat die ekumene in die Nederduitse Gereformeerde Kerk (NGK) binne algemene sinodale verband direk ná sy eerste Algemene Sinode in 1962 vanuit twee uiteenlopende motiewe bedryf is: 'n voorkeur vir 'n omskrewe verhouding met gereformeerde kerke in die binne- en buiteland, asook vir internasionale gereformeerde ekumeniese bewegings én breed omskrewe kontak met Protestantse kerke gerig op dialoog en gesamentlike projekte. Skakeling wat op 'n breë kerklike eenheid soos beliggaam in die Wêreldraad van Kerke (WRK) gemik is. Sommige praat van twee ekumeniese denkskole in die NGK: die meer gereformeerde en die meer algemene groep (Strauss 2002:383).

'Ekumene' word hier gebruik as 'n term vir betrekkinge tussen Christelike kerke ${ }^{1}$ waarvan die dieper doel die geloofs- en strukturele eenheid van die kerk van Christus op aarde is (Crafford \& Gous 1993:5). Daarby dui die aanvangs- en sluitingsdatum (1962 en 2015) van ons tema op uitstaande datums in die ekumene van die Algemene Sinode van die NGK. Datums wat die verhoudinge van hierdie kerk deur sy Algemene Sinode met ander kerke en ekumeniese liggame as sy jonger NGK-familie raak. In 1962 vergader die eerste Algemene Sinode as die verteenwoordiger van die NGK in ekumeniese betrekkinge met sy nuwe algemene sinodale verband, terwyl die NGK in algemene sinodale verband in 2015 die eerste keer as ' $n$ lid by die WRK verwelkom word (NGK 2007:406; Strauss 2015:80-81, 2018:125).

Die feit dat die eerste Kerkorde van die NGK in hierdie algemene sinodale verband, die Kerkorde van 1962, 'n gereformeerde koers met ekumene inslaan, toon die oorheersende invloed van die gereformeerde denkskool in die saak. J.D. Vorster, 'n verteenwoordiger van die gereformeerde denkskool wat leiding neem by die opstel van die Kerkorde (NGKO 1962), skryf waarskynlik die 1.'n Onchristelike kerk is natuurlik nie' $n$ kerk nie (Kock 1975:142-144). 
eerste vier van ses hoofstukke en redigeer die res (Langner 2007:87). As 'n erkenning van sy kennis van kerkordes, wys die Algemene Sinode van 1962 hom as die aktuarius of kerkregkundige van die Sinode en die voorsitter van sy Algemene Regskommissie aan (Van der Watt 1973:165). Vorster noem die konsep van NGKO 1962 in 1960 die 'Dordtse Kerkorde (die DKO van 1619 van die Gereformeerde Kerke in Nederland of net DKO 1619) aangepas by die eise van ons dag' (Vorster 1960:13). 'n NG-Kerkorde wat die Kerkorde van 1959 van die Gereformeerde Kerke in Nederland (GKN-KO) as voorbeeld gebruik en sommige van sy bepalings woordeliks oorneem (NGKO 1962:2, 5, 2015:1,7). GKN-KO 1959 is destyds in die NGK as 'n eietydse weergawe van DKO 1619 beskou (NGK 1957:73-74). Wat Vorster betref, is die oriëntasie van NGKO 1962 op DKO 1619 via GKN-KO 1959 nie onverwags nie, maar "n natuurlike vrug, 'n logiese gevolg, 'n sluitsteen, 'n verwagte klimaks in die kerkregtelike ontwikkeling van die NG Kerk' (Vorster 1960:13,17). Dit is dus nie vreemd dat die NGKO 1962 artikel 70 onder die opskrif 'Die (NG) Kerk en ekumeniese betrekkinge' 'n Nederlands-gereformeerde sirkel- of gradebenadering gebruik nie (Nauta 1971:449; NGKO 1962:16). Hierteenoor toon die algemene denkskool in die NGK deurgaans 'n ongevoeligheid teenoor hierdie benadering. Daarna kom ons terug.

Die vraag wat hierdie artikel ondersoek, is: hoe het die NGKO in 1962-2015 sy bepalings oor die NGK en ekumeniese betrekkinge verwoord én het die Algemene Sinode die bepalings uitgevoer? Het die grade- of sirkelbenadering in ekumene in die NGK, sy Algemene Sinode en gemeentes geleef? Hoe het die algemene denkskool op NGKO 1962 gereageer? En het die Kerkordes wat NGKO 1962 opgevolg het, naamlik NGKO 1966, 1970 ensovoorts, in dieselfde spoor geloop?

\section{Etiese oorwegings}

Hierdie artikel volg alle etiese standaarde vir navorsing sonder direkte kontak met mense of diere.

\section{DKO artikel 85}

In die lig van die feit dat NGKO 1962 as die DKO aangepas by die eise van die dag beskou is, moet die invloed van die DKO op NGKO 1962 artikel 70 vir die NGK in sy ekumeniese betrekkinge ontleed word. Dat NGKO 1962 via die GKN-KO 1959 'n eietydse weergawe van die DKO of die DKO aangepas by die eise van die dag wou wees, moet op hierdie punt ook verreken word. Hiernaas kon die ervaring van die ekumene van die NGK op sinodale vlak, voor die vorming van sy algemene sinodale verband in 1962, NGKO artikel 70 ook beïnvloed het. Dit is nie onmoontlik dat die praktiese ervaring van ekumene in die NGK - in die binne- sowel as die buiteland - tot sommige formulerings in NGKO 1962 oor ekumene gelei het nie.

Nauta (1971:450) wys daarop dat die 16e- en 17e-eeuse Gereformeerde Kerk in Nederland min tot geen aandag aan ekumene met buitelandse kerke gegee het nie. Onder 'Buitenlandsche kerken' bepaal DKO 1619 artikel 85 kortweg: in 'middelmatige dingen' sal die Gereformeerde Kerk ander kerke 'niet verwerpen, die ander gebruiken hebben dan wij' (Pont 1981:186). Wat die DKO hier met 'gebruiken' bedoel, word duideliker uit wat die sinodes in die $16 \mathrm{e}$ eeu van die Gereformeerde Kerk in Nederland wat DKO 1619 met hulle eie Kerkordes voorafgaan, in hierdie Kerkordes daarvan gemaak het (Strauss 1991:193). Rutgers (in De Jong 1918:163-175) vat raak met sy stelling dat dit om ritusse en seremonies in die erediens en by die bediening van die sakramente ${ }^{2}$ om 'adiaphora' of randsake gaan. Hy haak in by Calvyn én Dordt dat middelmatige sake in die kerkleer nie die eenheid van Christelike geloof moet versteur nie (Sizoo s.a.:8-15). Volgens sy interpretasie van DKO artikel 85 mag gebruike nie in die weg van kerkverband tussen gemeentes of van 'correspondentie' tussen kerke van dieselfde belydenis en 'grondslagen van kerkinrichting' staan nie (De Jong 1918:163-175). Korrespondensie of betrekkinge wat impliseer dat hierdie kerke of gemeentes, indien dit geografies moontlik was, in een sinodale verband sou verenig het.

Met hierdie verstaan van die Nederlandse gereformeerde of Dordtse tradisie loop Rutgers in die spore van Calvyn en word hy deur gereformeerde kerkregtelikes soos Van der Linde (1983:275), Spoelstra (1989:468-469) en De Gier (1989:417) ondersteun. Daardeur word 'n grondlyn vir die ekumene of die strewe van gereformeerde kerke na eenheid op die agenda van NGKO 1962 geplaas (Strauss 1991:194).

Die Algemene Sinode van 1990 van die NGK vat die lyn oor kern- en randsake verder as hy aanvoer dat die ekumeniese strewe na kerkeenheid nie 'n strewe na kerklike eendersheid is nie. Volgens die NGK word die geestelike en geloofseenheid tussen kerke nie verhinder deur 'n eie geskiedenis, taalgebruik, omstandighede, liturgieë, sangbundels én belydenisskrifte en kerkordes wat in verskillende situasies ontstaan nie. Leerstellinge en kerklike eenheid loop op kernsake van die geloof en druk 'ingrypende verskille oor Bybelse waarhede' of middelmatige sake na die rand - waar hulle hoort (NGK 1990:547-548). Die Algemene Sinode van 1990 werk dus in die verlengde van Dordt met sy onderskeid tussen kern- en randsake.

Wat DKO 1619 artikel 85 dus op die ekumeniese agenda van die gereformeerde kerke in sy tradisie plaas, is dat die voorwaardes vir ekumene wat lei tot kerkeenheid nie verskil van die voorwaardes vir 'n gereformeerde kerkverband nie. Voorwaardes wat harmonieer met die wyse waarop gemeentes in die NGK mekaar in kerkverband hanteer, sy hantering van geesgenootlike gereformeerde kerke en die oorkoms van lidmate uit die gemeentes van hierdie kerke na sy gemeentes (NGKO 2015:107-117). Daarmee staan die ekumeniese vertrekpunte van die NGK nie los van die uitgangspunte vir die bediening in gemeentes nie. Inteendeel, dit impliseer dat die ekumene vanuit die gemeentes as die

2. Hierdie gebruike by die bediening van die sakramente word deur Emden in 1571 uitgewys as byvoorbeeld een of drie keer se besprinkeling by die doop in die Naam van die Drie-enige God (Pont 1981:105). 
kern van kerkwees gestimuleer word. Dat die gemeentes en kerkverband, beide op hulle terrein, geroep is om ekumenies aktief te wees. Wat DKO artikel 85 deurgee, is dat daar die nouste ekumeniese band van gereformeerde kerke, vanweë die aard en inhoud van hulle kerkwees, met ander gereformeerde kerke is. Kerke wat een in belydenis of kernsake van die geloof en in hoofsake van kerkregering is. Hierdie stelling onderstreep 'n sirkelbenadering in ekumene: belydeniskerke nader aan jou is ook kerklik-ekumenies nader aan jou as kerke met ander oortuigings. Nauta het dus gelyk dat die ou Nederlandse Gereformeerde Kerk, met sy klem op ander gereformeerde kerke as ekumeniese vennote op pad na daadwerklike kerkeenheid, in beginsel reg is, maar dat dit nie die enigste ekumeniese weg vir gereformeerde kerke mag wees nie. Die algemene Christelike kerk wat hierdie kerke bely, sluit gelowiges uit alle kerke in (Nauta 1971:450). Volgens hom moes die GKN-KO 1959 hierdie korreksie op die DKO aanbring.

\section{GKN-KO 1959 artikel 127-129}

Onder die opskrif 'Betrekkingen van de kerk naar buiten' begin die GKN-KO 1959 artikels 127-129 vir die GKN as 'n gereformeerde kerk, by gereformeerde kerke. Met buitelandse kerke van gereformeerde belydenis en kerkregering sal die GKN deur middel van 'correspondentie zoveel mogelijk christelijke gemeenschap' beoefen: gemeenskap deur korrespondensie in 'n 'engere' en 'ruimere' sin. Engere korrespondensie sluit die wedersydse erkenning van die lidmaatskap en attestate van lidmate, 'n oor en weer toelating van bedienaars tot die bediening van die Woord en sakramente en die stuur van gesante na die sinodes van die ander kerk in. Dit is korrespondensie wat gevoer word met kerke 'in het buitenland' wat die belydenis 'metterdaad handhaven'. Met ander kerke ongekwalifiseerd - is slegs ruimere korrespondensie moontlik. Laasgenoemde bestaan dan uit die stuur van afgevaardigdes na mekaar se sinodes (Nauta 1971:449, 456).

Uit GKN-KO 1959 artikel 127 volg dat ander binnelandse gereformeerde kerke (in Nederland is daar talle) nie vir engere korrespondensie kwalifiseer nie, omdat 'n gemeenskaplike belydenis en dieselfde tipe kerkregering beteken dat hulle en die GKN een kerkverband in die een land -'n sinodale verband - moes gevorm het. 'n Kerkverband wat die oor en weer erkenning van lidmaatskap en die toelating van ander kerke se bedienaars van die Woord tot die bediening van die Woord en sakramente as 'n normale praktyk beoefen. Deur nie in korrespondensie met hulle te tree nie, weerhou die GKN sy sanksie en goedkeuring van wat beskou kan word as 'n sondige, strukturele verskeurdheid te midde van 'n eenheid in belydenissake. Daardie soort eenheid tussen gemeentes wat lei tot een kerkverband. Wat GKN-KO artikel 127 wel oopmaak, is die moontlikheid van 'n ruimere korrespondensie met nie-gereformeerde kerke.

In sy kommentaar op hierdie artikel voer Nauta (1971:450-453) aan dat ooreenstemming in belydenis en kerkregering onder gereformeerde kerke gerig is op 'de grote lijnen'. Hy beaam dus die Algemene Sinode van 1990 van die NGK se onderskeid tusen kerkeenheid en kerklike eendersheid. Daarmee bevestig hy 'n belangrike gereformeerde uitgangspunt vir die ekumene én vir sinodale kerkeenheid (Strauss 2010:84). Vir Nauta is Christelike geloofsgemeenskap deel van die wese van die kerk. Daarsonder verloor 'n kerk sy reg op bestaan as kerk. Hierdie gemeenskap vind in Christus sy grondslag en krag. Kerke moet hulle met mekaar 'in ... laten' en in hulle gemeenskap 'iets voor elkander ... zijn ...'. Korrespondensie in die ekumeniese sin van die woord het ' $\mathrm{n}$ 'technische term' onder gereformeerdes geword. Om een of ander rede glo Nauta egter nie dat die onderskeiding van hierdie twee soorte korrespondensies lank deur die GKN-KO gebruik sal word nie. Hy ontken nie dat gereformeerde kerke die belydenis 'metterdaad' moet handhaaf nie. Daarsonder ontbreek 'de waarborg van een getroue ambtsbedieningen van een zuivere belijdenis en wandel der leden'. Nauta volstaan met die bepaling dat die Generale Sinode van die GKN betrekkinge na buite bepaal (Nauta 1971:450-453).

Die ooreenkomste tussen GKN-KO 1959 artikel 127 en NGKO 1962 artikel 70 is opvallend.

\section{NGKO 1962 artikel 70 en sy opvolgers}

NGKO 1962 artikel 70(b) neem GKN-KO artikel 127.1 woord vir woord oor. Soos artikel 127.1 in GKN-KO 1959, gebruik NGKO 1962 artikel 70(b) die term 'korrespondensie' met kerke van gereformeerde belydenis en kerkregering in die buiteland ook ongekwalifiseerd. Omdat hierdie korrespondensie in 1962 egter as 'n Fremdkörper in die NGK oorkom, word dit verduidelikend maar verskralend aangevul met slegs een van die sake wat die GKN onder engere korrespondensie plaas: 'hulle emigrerende lidmate sal met attestasie ontvang word'. NGKO 1962 artikel 70 (b) soek, soos GKN-KO 1959 artikel 129 in sy 'contact' met 'andere' kerke, moontlik ook 'kontak' met kerke van 'n 'algemeen Protestants-Christelike belijdenis'. Hy wil dus ook kerkeenheid in die algemeen bevorder. Verder as die Protestantse kerke kom hy egter nie. Vanuit sy ekumeniese geskiedenis - breër as dié van die 16e-eeuse Gereformeerde Kerk in Nederland wat net op gereformeerdes gerig was was ekumene buite die Protestantisme vir die NGK teen 1962 ondenkbaar en dus onbestaanbaar. Verder het sy kerklik-teologiese verbondenheid met die GKN, die enigste buitelandse kerk met wie hy engere korrespondensie of susterskerkverhoudinge gehad het (GKN Rotterdam 19521953, artikel 294; Strauss 1983:64-69), die gereformeerde ekumeniese voorkeure van die NGK in hierdie stadium gestimuleer. $^{3}$ Soos die Generale Sinode van die GKN, het die Algemene Sinode 'die aard en/of graad' van ekumeniese betrekkinge bepaal. NGK-lidmaatskap van internasionale kerklike organisasies 'op ekumeniese grondslag' moes egter met 'n tweederdemeerderheid van die Algemene Sinode beslis word (NGKO 1962:16). Hierdie bepaling in NGKO artikel 70(d) volg op die trauma van Sharpeville en ander plekke van onrus in Suid-Afrika in 1960 en die kritiese

3.Die ekumeniese betrekkinge van die vyf sinodes wat in 1962 die algemene sinodale verband van die NGK sou vorm, was beperk tot binnelandse en buitelandse Protestantse kerke (vgl. Strauss 2015:76-90). 
Cottesloe-beraad - oor apartheid - wat in Desember 1960 as 'n kerkeberaad van sy Suid-Afrikaanse lidkerke op inisiatief van die WRK gehou is. 'n Beraad wat diep spore op die ekumene en die emosies rondom die ekumene van die NGK in die volgende dekades gelaat het (Strauss 1989:156-161). Die gereformeerde denkskool wat pro-apartheid ingestel was en wie se invloed op NGKO 1962 sterk was, wou toekomstige lidmaatskap van die WRK deur die NGK met hierdie bepaling bemoeilik. Dieselfde denkskool is deur die anti-Cottesloe en anti-WRK-sentiment wat ná 1960 deur die NGK gespoel het, versterk. 'n Denkskool wat die NGK deur sy Algemene Sinode aan gereformeerde liggame soos die Gereformeerde Ekumeniese Sinode (GES) en Presbiteriaanse Wêreldalliansie (PWA), in 1962 en 1966 onderskeidelik, eerder as aan die WRK verbind het (Strauss 2002:383-384, 2018:124).

Wat opvallend in NGKO 1962 artikel 70 is, is uitdrukkings en gedagtes wat aan die GKN-KO en daarmee aan sy Dordtse agtergrond ontleen is. Die grade- of sirkelbenadering in die Nederlands-gereformeerde ekumene word by implikasie, maar verskraald, oorgeneem. In dieselfde gebrekkige trant word kontak ('n enkele draadjie van ekumene!) in plaas van geloofsgemeenskap met Protestantse kerke binne- en buitelands gesoek. NGKO 1962 skep sy eie weergawe van die GKN-KO se ekumeniese middele as hy met gereformeerde kerke in die buiteland deur middel van korrespondensie (dit word nie omskryf nie) gemeenskap wil beoefen én hulle emigrerende lidmate met attestasie wil ontvang. By NGKO 1962 artikel 70 staan korrespondensie en die ontvangs van lidmate uit ander kerke, anders as in die GKN-KO, dus los van mekaar (NGKO 1962:16). By die verbreking van sy 'bande' met die GKN in 1976 bly die NGK in gebreke om die aard van dié bande ná die breuk te omskryf - selfs op 'n vraag van die GKN oor wat nou prakties gebreek is. Ná die Algemene Sinode van 1978 stuur die Direkteur van Ekumeniese Sake van die NGK, F.E. O'Brien Geldenhuys, aan die GKN 'n boodskap dat die NGK sy bande met die GKN tans beskou as bande met 'n kerk met wie hy 'geen besondere bande het nie' (Korrespondensielêers GKN-NGK 1974-1979). Meer niksseggend en afsydig kan hy beslis nie wees nie. Nie NGKO 1962 artikel 70 - gehandhaaf in NGKO 1974 én NGKO 1978 artikel 70 - of kommentaar daarop kon die situasie beredder nie. In 1978 bepaal NGKO 1978 artikel 70 - soos NGKO 1962 artikel 70 - steeds dat die NGK met kerke van gereformeerde belydenis en kerkregering in die buiteland deur middel van 'korrespondensie Christelike gemeenskap' beoefen én hulle 'emigrerende lidmate ... met attestasie' ontvang (NGKO 1978:19).

Die erkenning van lidmaatskap en attestate oor en weer word deur die NGK dus nie woordeliks by korrespondensie ingesluit nie. Maar omdat NGKO 1974 sy korrespondensie nie uitdruklik omskryf nie, kon hierdie verbreekte korrespondensie as term vir die NGK se 'bande' wel blote gesprek of 'n verkennende kontak insluit. Of het die NGK die GKN, op grond van die sinodale sake waaroor hulle verskil, so ver weggestoot dat hy hom uitsluit van enige gesprek? Het die NGK die GKN verban soos in die uiterste konsekwensie van 'n tugsaak? Sommige in die NGK het die verbreking van bande beskou as nie net die opsê van die besonderhede van die bestaande verhouding tussen die NGK en GKN nie, maar selfs van gesprek (Strauss 1992:76-77). Die Algemene Sinode, as die vertolker van sy eie Kerkorde en besluite, het hierdie onduidelikheid nooit opgeklaar nie. 'n Ekstra besluit oor die 'verbreekte bande'-besluit van 1974 op sigself sou ook 'n verleentheid wees omdat dit 'n onvolledigheid aan die kant van die NGK impliseer. Ná vier jaar se gebruik van 'verbreekte bande', waarin sommige mense aanvaar het dat dit die beëindiging van gesprek kan beteken, het die saak tot 'n onopgeloste einde gekom. 'n Einde waarvoor figure by NGKO mede-aanspreeklikheid moes aanvaar (Strauss 1992:76-77). 'n Einde waarvan die algemene denkskool in die NGK kerklik en teologies uitgesluit was en waartoe hulle ook nie 'n bydrae gelewer het nie. Die gesprekke met die GKN in 1968, 1970, 1974 en 1975 is deur lede van die gereformeerd geneigde moderatuur gevoer wat die saak met geesgenote hanteer het (Strauss 1983:219, 273, 367-368, 420) Dit is dus moontlik dat die algemene denkskool met hulle stilte oor kerkorde en ekumene, oor NGKO 1974 artikel 70, die speelveld vir die dominerende gereformeerde skool oopgelaat het.

Met betrekking tot die enigste buitelandse gereformeerde kerk met wie die NGK 'naby' ekumene of 'bande' gehad het, was NGKO artikel 70 dus nie verhelderend of bruikbaar nie. Hierdie situasie sou eers met NGKO 1998 verlig word (NGKO 1998:27).

\section{NGK geïsoleer}

Voordat NGKO 1962 artikel 70 deur die Algemene Sinode van 1998 gewysig is, sou die NGK in 1974-1986 - ná die ultimatumbesluit van die Algemene Sinode van 1974 teenoor die GKN en voor die interne wending oor apartheid deur die Algemene Sinode van 1986 met Kerk en Samelewing 1986 ekumenies geïsoleer word (Strauss 2002:183). Sy teologiese en morele steun aan apartheid, soos dit deur kritici genoem is (Perret, die Algemene Sekretaris van die WBGK in 'n brief aan die NGK soos in NGK 1982:1018; Strauss 2004:105), was die rede hiervoor. Ná die sogenaamde verbreking van sy 'bande' met die GKN in 1978, sou die NGK as 'n lidkerk by die Wêreldbond van Gereformeerde Kerke of WBGK (hierdie naam vervang PWA in 1970) in 1982 en by die GES in 1984 (hy word die Gereformeerde Ekumeniese Raad of GER in 1988) skerp onder skoot kom. Sy lidmaatskap van dié liggame was in daardie stadium die enigste omskrewe buitelandse ekumeniese betrekkinge van die NGK. Stram betrekkinge met hierdie twee liggame sou ook 'n stremmende invloed hê op die houding van buitelandse gereformeerde kerke teenoor die NGK (Strauss 2004:108-110). By Ottawa 1982 word die NGK deur 'n meerderheid van 220-20 deur die Algemene Vergadering as 'n lid van die WBGK geskors (Perret in NGK 1982:1018). Die stemtotale toon dat die NGK vir sy steun aan apartheid min steun uit die gereformeerde kerke teenwoordig gekry het. Boonop verklaar die WBGK dat sy weerstand teen die teologiese en morele regverdiging van apartheid op die 
vlak van 'n status confessionis (die vlak of status van 'n belydenis as die sterkste vorm van kerklike afkeur) lê. Die NGK is volgens hom skuldig aan 'n dwaling oor 'n fundamentele waarheid van die Evangelie, naamlik dat alle mense gelyk geskape is as beelddraers van God (NGK 1982:1020-1024). Teenoor hierdie veroordelende besluit van die WBGK, versoek die GES-1984 die NGK en die Gereformeerde Kerke in Suid-Afrika (GKSA) om hulle self te toets of hulle met hulle steun aan apartheid aan dwaalleer of 'n ideologie soos deur die GES omskryf, skuldig is. Hulle moet in 1986 daaroor aan die Interimkomitee rapporteer. Ook die GES, die NGK se naaste kerklike familie of gees ge no te in die wêreld, oordeel dat 'n status confessionis hier ter sprake is (RES 1984:90vv). By die GES-1992 in Athene steun die afgevaardigdes van die NGK 'n besluit wat apartheid in al sy vorme, teoreties en prakties, tot sonde verklaar. Die NGK se reaksie op hierdie besluit stel die GES tevrede en sy lidmaatskap van die GES word genormaliseer. Gevolglik stap die GES af van die NGK en apartheid as 'n agendapunt (REC 1992:18). In 1998 aanvaar die Algemene Sinode van die NGK 'n besluit van die WBGK-Debrecen van 1997 oor die verwerping van apartheid wat die WBGK tevrede stel. Die WBGK praat van die 'forced separation' van verskillende rasse wat die fundamentele Bybelse waarheid - 'it cannot be denied by Christians' - ontken dat alle mense gelyk geskape is 'in the image of God' (NGK 1998:412vv; WRK-Argief Ref 215/9.2.2.1/10).

Ná 1962, veral in die kritieke jare 1974-1986, speel NGKO artikel 70 geen beduidende rol in die buitelandse ekumene van die NGK nie. Binnelands word die verhouding van die NGK met twee ander Afrikaanse gereformeerde kerke, die Nederduitsch Hervormde Kerk van Afrika en die Gereformeerde Kerk in Suid-Afrika, in die Tussenkerklike Kommissie bestendig, die minimale kontak met kerke buite hierdie kring behou en die verhoudinge in die NGK-familie algaande versuur. Wat die buiteland betref, is die 'bande' met die GKN in 1974-1978 verbreek sonder dat 'n onbekookte NGKO 1974 òf NGKO 1978 artikel 70 - die twee NGKO's van destyds - van hulp kon wees. Die gereformeerde denkskool wat 'n deurslaggewende aandeel in die opstel van NGKO artikel 70 by Algemene Sinodes sedert 1962 gehad het, het ook nooit die omstrede word 'band' (Engels 'tie') wat J.D. Vorster in sy ultimatumvoorstel van 1974 gebruik het, verduidelik of omskryf nie. Gesien die denkwêreld waaruit NGKO artikel 70 kom én die formulering van die artikel, was 'bande' 'n kerkordelik vreemde, misleidende 'term'. Op sigself beskou is 'n bestaande band immers vas en 'n verbreekte band heeltemal los. Tog het die NGK sy verstaan van kerklike bande nie verduidelik nie. As die GKN die onduidelikheid oor die 'verbreekte bande' soos geloods vanuit die NGK op die spits wou dryf, sou dit die morele laagtepunt waarop die 'bande' beëindig is, vererger het. Sou rooi gesigte in die NGK oor die onverklaarde, onduidelike 'bande' verdiep het (Die Burger 17 Oktober 1974:1).

Die gewraakte tweederdemeerderheid van die Algemene Sinode vir lidmaatskap van die NGK van ekumeniese liggame was in 1962-1986 ook nie dienstig aan die gereformeerde denkskool nie. Hierdie bepaling is wel by die Algemene Sinode van 1986 suksesvol téén die Breë Moderatuur gebruik wat die NGK ná die kritiek van die GES-1984 op sy steun aan apartheid uit dié liggaam wou neem. Die Breë Moderatuur kon nie'n tweederdemeerderheid vir sy voorstel tot, soos hy dit opnuut gestel het, 'verbreekte bande' met die GES kry nie. Hy het dus gestuit op die, vir hom, aanvaarde kerkordebepaling uit 1962 wat 'n nuwe NG-aansoek om lidmaatskap van die WRK ná Cottesloe in 1960 wou verhoed (NGK 1986:661).

Van 'n duidelike gereformeerd-kerkordelike begrip in omvattende ekumene was daar in die NGKO op hierdie stadium nie sprake nie.

Teen 1986 was die NGK tydelik uit die WBGK geskors, moes hy nog reageer op 'n ernstige versoek van die GES om sy gereformeerde identiteit in die oë van hierdie kerke te behou én het sy betrekkinge met indiwiduele gereformeerde kerke in die buiteland afgekoel of tot stilstand gekom. Daar was nie gedefinieerde kerklike 'bande' met 'n buitelandse kerk nie. NGKO artikel 70 het geen rol in die ekumene van die NGK gespeel nie omdat dit onbruikbaar was. Die groot rede vir die isolasie van die NGK was sy steun aan apartheid. Boonop was NGKO artikel 70 grootliks onbruikbaar. Ten opsigte van apartheid het buitelandse geesgenote vir 'n wending gevra. ' $n$ Wending wat sy posisie in beide die GES en WBGK sou herstel. Dit is aangetoon. Oor artikel 70 was daar - soos dit soms met hierdie sake in die NGKO gaan geen debat in die NGK nie. As daar debat was, was dit binne die mure van die Algemene Regskommissie van die Algemene Sinode. Die NGK in algemene sinodale verband het die kwessie van 'kerkorde en ekumene' nie deeglik gedebatteer en deurtrap nie. Daarom het die kerkregtelik vreemde begrip 'bande' ná 1974 die effense gesprek wat daar wel was, vir meer as 'n dekade onwillekeurig oorheers. NGKO artikel 70 oor die ekumene was nie 'n lewende, goed deurwrogte rigsnoer vir die Algemene Sinode of NGK-gemeentes nie.

Ná 'n regeringsoordrag en die amptelike afskeid van staatkundige apartheid in Suid-Afrika in 1994, sou die NGK hom in 'n nuwe, veranderde ekumeniese situasie bevind. Sy steun aan apartheid was die bepaler van sy ekumene in 1962-1998. Met die verdwyning van wetlike apartheid en die NGK se herhaalde gedefinieerde en later volle verwerping daarvan in 1986-1990-1994-1998 (Meiring 2008:203; Strauss 2004:110-111), sou die tema 'NGK en apartheid' ná 1994 van ekumeniese agendas verdwyn (Strauss 2002:391-393). Die NGK was ekumenies weer aanvaarbaar.

\section{NGK in 'n nuwe ekumeniese situasie}

Kerkhistories beskou was die Algemene Sinode van 1998 se aanvaarding van die 'joint resolution' van die WBGK in 1997 by Debrecen sy eie formele afskeid van apartheid (NGK 1998:412-413; WRK-Argief Ref 215/9.2.2,1/10). Soos by die GES-Athene 1992 het die NGK hier 'n formulering aanvaar 
waarvoor hyself nie verantwoordelik was nie en waarop hy aanvaarbaar of reg moes reageer. In beide gevalle is sy steun aan apartheid in die skerpste kerklike taal veroordeel. Hierdie prosedure was skynbaar vir die ekumeniese wêreld én vir gemeentes of lidmate van NGK-gemeentes aanvaarbaar. Vanuit laasgenoemde is die besluit van die Algemene Sinode om die 'joint resolution' van die WBGK te aanvaar in stilte en sonder 'n duidelike teenstem aangehoor. Vanuit die ekumeniese gemeenskap is die NGK ná 1992-1998 hartlik, byna soos die verlore seun, deur indiwiduele kerke en ekumeniese liggame ontvang (Strauss 2013:46).

Sonder die las van apartheid is die NGK onmiddellik in ekumeniese organisasies binne en buite Suid-Afrika opgeneem en sy verteenwoordigers op besture en komitees verkies. Los van die NGKO en sy ekumene het die insig by die Algemene Sinode posgevat dat sy deelname aan 'n ekumeniese liggaam nie beteken dat die algemene vergadering van hierdie liggaam 'n supersinode word en die NGK medeverantwoordelikheid vir al sy besluite aanvaar nie. Die insig het begin groei dat ekumeniese liggame praatforums is waar kerke uit vrye wil besluit om sake saam te omskryf en te pak (Strauss 2015:81). Daarmee het die rede vir NGKO 2015 artikel 70.4 se tweederdemeerderheid van die Algemene Sinode om tot 'n ekumeniese liggaam toe te tree (NGKO 2015:22) bloot van akademiese belang geword. Die oorgrote meerderheid by opeenvolgende Algemene Sinodes wou ten alle koste wegkom van die beeld van die NGK as 'n ekumeniese swartskaap.

Op versoek van die Algemene Sinode van 1994 (NGK 1994:591) word die NGK in 1995 by die Suid-Afrikaanse Raad van Kerke (SARK) - 'n opponent en vreemdeling vir die NGK sedert die stigting van die SARK in 1968 - as 'n lid met waarnemerstatus verwelkom. In sy uitgebreide verslag oor ekumene -'n nuwe bries in die agendas van die Algemene Sinode - aan die Sinode van 2002 vermeld die Algemene Sinodale Kommissie (ASK) dat die harte en deure van kerke in die SARK vir die NGK 'letterlik' oopgegaan het. Sedert 1994 behandel die SARK die NGK asof laasgenoemde oor volwaardige lidmaatskap beskik. Die NGK word by alle aksies van die SARK betrek en een van sy dominees is selfs die voorsitter van die Finansiële Komitee. Talle NGK-sinodes werk met streeksrade van die SARK en selfs in gemeentes is daar gesamentlike projekte (NGK 2002:392). In sy motivering vir die NGK om volle lid van die SARK te word, gebruik die ASK onder meer die argument dat die SARK 'net 'n adviserende liggaam is wat lidkerke nie kan bind aan besluite nie' (NGK 2002:391-392). Lidkerke kan die besluite van die SARK 'na goeddunke' hanteer (NGK 2002:391-392). Hierdie houding bring mee dat die NGK hom van enige besluit van die SARK kan distansieer en nie gebonde is aan al die besluite van hierdie liggaam nie. Dit was in die 1960's en later in tye van ernstige verskille met die SARK 'n ernstige probleem by die NGK. In 2004 gee die SARK gehoor aan die versoek van die Algemene Sinode om volle lidmaatskap aan die NGK te verleen (Strauss 2015:82).
In 2007 besluit die Algemene Sinode, ná besinning van meer as 'n dekade, om aansoek te doen om lid van die WRK te word. Sy redes is drieledig: die WRK is net 'n oorlegplatform vir kerke en nie 'n supersinode nie, lidmaatskap skep die moontlikheid vir kontak met kerke oor die wêreld heen én die NGK kan sy getuienis hier in 'n wêreldwye kerkegemeenskap lewer (NGK 2007 I:404-406; III 201). In 2015 verwelkom die WRK die NGK as 'n volle lid (Strauss 2018:125).

Naas ekumeniese instellings soos die WBGK, wat in 2010 die Wêreldgemeenskap van Gereformeerde Kerke (WGGK) word en by hierdie geleentheid verenig met die kleiner GER, soos die WRK en die SARK, skakel die NGK ná 1994 buitelands in by die Lausanne-beweging, World Reformed Felllowship, Global Christian Forum en Communion of Reformed Churches in Africa. Laasgenoemde is ' $n$ streeksliggaam van die WGGK. Binnelands word die NGK 'n lid van die Konvent van Reformatoriese Kerke in Suider-Afrika en die Evangelical Alliance of South Africa, terwyl hy sy lidmaatskap van die Tussenkerklike Raad (TKR) van die drie Afrikaanse Kerke en die Federale Raad van die NG-familie voortsit (NGK 2011:250-253; NGKO 2002:36,). Daarmee wis die NGK nie net sy isolasie van 1974-1986 uit nie, maar word hy ook meer betrokke by ekumeniese verhoudinge as voor Cottesloe.

\section{'n Nuwe blaadjie vir NGKO 1998}

Intussen sou NGKO artikel 70, wat in 1986 NGKO artikel 71 (NGKO 1986:20-21) en in 1998 NGKO artikel 68 word (NGKO 1998:27), in 1998 'n nuwe blaadjie omslaan. Die nuwe artikel begin met die NGK se voorneme om met 'ander Christelike kerke' - ongekwalifiseerd - saam te werk en 'n gemeenskaplike boodskap uit te dra. Die 'aard en graad' van betrekkinge met ander kerke of kerkgemeenskappe (die NGKO gebruik hierdie 'Dopper'-term vir'n kerkverband tussen gemeentes as, in gereformeerde terme, volledig kerk) word bepaal deur 'n gewone meerderheidstem van die Algemene Sinode. Op hierdie punt word die tipies gereformeerde grade- of sirkelbenadering gebruik as bepaal word dat die graad en wyse van kerklike samewerking bepaal word deur 'die graad van ooreenstemming' ten opsigte van die belydenis, regering, erediens en opvatting van die Christelike lewenswandel van 'die betrokke kerk'. NGKO 1998 artikel 68 brei dus die gereformeerd beproefde eenheid in belydenis en hoofsake van kerkregering uit met die erediens en die siening van die Christelike lewenswandel. Die onmiddellike vraag wat hieruit ontstaan is of die erediens in sommige NG-gemeentes in die NG-kerkverband nie al so ver van die NGK se grondlyne vir die erediens soos bepaal deur die Algemene Sinode afgewyk het, dat die vereistes vir ekumene hieroor nou hoër gemaak word as vir sy eie gemeentes in sinodale verband nie (Strauss 2013:124). Daarby plaas die Christelike lewenswandel soos dit hier gebruik word etiese lewenskwessies op dieselfde vlak as belydenis- of kernkwessies van die Christelike geloof. Dit gaan oor etiese vrae wat nie, soos belydenisskrifte en hoofsake van kerkregering, hulle tyd van ontstaan oorstyg nie. 
Die Christelike lewenswandel loop inhoudelik soms so wisselend en wyd dat ' $n$ konstante eenheid van oortuigings daaroor as 'n basis vir ekumene na 'n onbegonne saak lyk. Is die doel van NGKO artikel 70 dat kerklike betrekkinge bepaal word deur vloeibare - veral ten opsigte van die grade van weerstand daarteen en die openbare ergerlikheid daarvan - kwessies rondom sake soos egskeiding en homoseksualiteit? Kan kerklike verhoudinge bestendig op onbestendige, wisselende besluite oor aktuele kwessies? ${ }^{4}$ Word die besluite van elke Sinode van gereformeerde kerke oor lewenskwessies 'n potensiële maak of breek vir verhoudinge met die NGK?

Ten opsigte van lidmaatskap van ekumeniese organisasies handhaaf NGKO 1998 die bepaling dat die Algemene Sinode met ' $n$ tweederdemeerderheid daaroor besluit - 'n reëling wat die kerkregtelike wenkbroue steeds laat lig. Die vraag is of die verhouding met'n gereformeerde kerk wat jou kansels en die bediening van die sakramente in gemeentes vir hom oopstel, met ander woorde 'n volle verhouding, minder belangrik is as jou plek op 'n kerklike praatforum. Of maak die groter getal kerke in ekumeniese liggame bloot vanweë hulle getalle meer indruk as 'n enkele kerk? Word die ware kerk volgens die Nederlandse Geloofsbelydenis nie eerder herken aan drie merktekens wat in die gemeente voorkom nie, naamlik die suiwere prediking van die Woord, die suiwere bediening van die sakramente en die handhawing van die kerklike tug (NG Kerk-Uitgewers 1982:29)? En, as die aanvaarding van belydenisskrifte ten grondslag van 'n suiwer prediking en bediening van die Woord afhang van 'n kerklike tweederdemeerderheid, lê deelname aan kerklike praatforums op dieselfde vlak? Dra dit net soveel gewig? Kan 'n gereformeerde kerk met sy ononderhandelbare klem op die gemeente as volledig kerk so 'n besluit neem? Waarom maak NGKO artikel 70 die lidmaatskap van adviserende vergaderings van kerke wat jou nié teen jou sin bind nie afhanklik van ' $n$ tweederdemeerderheid by die Algemene Sinode? Kan dit wat 'n kerk as blote advies kry, hom kompromitteer of diskrediteer? Is ongebondenheid of die gebrek aan ' $n$ verpligte instemming aan die besluite van die WRK nie juis een van die redes waarom die NGK 'n lid geword het nie? Sit die NGK nie hier opgesaal met 'n ongegronde emosionele res teen die WRK van bykans 60 jaar gelede nie? 'n Res wat in 1962 in 'n emosionele behoefte moes voorsien en sedertdien eenvoudig gekontinueer is? 'n Res wat daarna nie 'n belangrike faktor was en - met die uitsondering van sy lidmaatskap van die GES in 1986 - nie 'n rol in die NGK òf in sy beprekings oor ekumene gespeel het nie.

\section{NGK se ekumene groei}

In sy verslag aan die Algemene Sinode van 2002 oor ekumeniese verhoudings maak die Moderamen gewag van 'n verskeidenheid ekumeniese liggame in Suid-Afrika, Afrika en internasionaal waaraan hy behoort (NGK 2002:402-409;

\footnotetext{
4.vgl. Koffeman se afskeid van Woordgebonde kerklike tug. In sy Nederlandse situasie beskou hy dit net nie meer as 'n realistiese moontlikheid nie. Daarvoor is die etiese beskou hy dit net nie meer as ' $n$ realistiese moontlikheid nie. Daarvoor is die etiese
maatstawwe wat in sy kerkgemeenskap leef te relatief en beskou hulle die Bybel nie maatstawwe wat in sy kerkgemeenskap leef te relatief en beskou h
}

NGKO 2002:36). Die oorgrote meerderheid hiervan, waaronder 'n lys van Protestantse ekumeniese liggame, is reeds genoem. In 2002 is daar ook drie kerke in die buiteland met wie die NGK sy nuut omskrewe volle betrekkinge onderhou min of meer die GKN se ou korrespondensie - en 10 kerke met wie hy dialoogverhoudinge het. Na hierdie onderskeid word teruggekom. Die NGK is in 2002 ekumenies besiger as ooit tevore.

By dieselfde Sinode aanvaar die NGK 'n aantal uitgangspunte vir ekumeniese betrekkinge. Hierdie punte word as sinodebesluite aan NGKO artikel 70 toegevoeg. Daarvolgens strek die eenheid van die kerk van Christus oor die grense van tyd, plek, volk, taal, gebruike en kulture asook oor die verskeidenheid in aanbidding, konfessionele uitdrukkings, formuliere en kerkstrukture. Dit gaan om 'n komplementerende verskeidenheid in die eenheid van die kerk wat nie in 'n geskeidenheid moet ontaard nie. Kerke moet saam na die waarheid van die Woord van die Here soek. ' $n$ Waarheid wat nie ter wille van eenheid prysgegee moet word nie.

In die aanloop tot die uiteensetting van sy ekumeniese verhoudinge verklaar die NGK dat hy multilaterale verhoudinge met ekumeniese liggame én bilaterale verhoudinge met indiwiduele kerke in die binne- én buiteland het. Die multilaterale verhoudinge of lidmaatskap van ekumeniese liggame is vroeër uiteengesit. Onder bilaterale verhoudinge plaas die NGK, in die besluite by NGKO 2002 artikel 70, vier soorte verhoudinge. Verhoudinge wat, soos die res van die NGK se betrekkinge, deur die Ekumeniese Kommissie van die Moderamen onderhandel en by die Algemene Sinode vir 'n gewone meerderheid aanbeveel word (NGKO 2002:32-36).

Volgens sy gradebenadering kan die NGK met ander kerke volle, gedeeltelike, dialoog- of kontakverhoudinge aanknoop. 'n Volle verhouding word aangegaan met 'n kerk van gereformeerde belydenis. Dit omvat onder meer die stuur van afgevaardigdes na mekaar se sinodes, die wedersydse toelating van predikante op die kansels, 'n oor en weer toelating van lidmate tot die nagmaalstafel, gesamentlike optrede in sake van gemeenskaplike belang, die versorging van mekaar se lidmate waar nodig, die erkenning van mekaar se teologiese opleiding en die beroepbaarheid van predikante oor en weer. Laasgenoemde kan gebeur met inagneming van die spesifieke vereistes vir die bediening in die gemeente wat beroep.

Hierdie voorbeelde roep egter vrae uit 'n gereformeerdkerklike hoek op. Die eerste vraag is hoekom sommige belangrike kwessies verskralend uitgelaat is: die oor en weer erkenning van lidmaatskap en attestate; die toelating tot die doop; en eenheid in die hoofsake van kerkregering en -inrigting. Aan die positiewe kant word die 'bande' van 1974 nou omskryf en vaartbelyn gemaak. Dit is duidelik dat die Algemene Sinode glo dat ekumene kerkordelik nie koersloos mag wees nie en dat ' $n$ gereformeerde gradebenadering van 
'n duidelike inhoud voorsien moet word. Sy verwysing in NGKO artikel 70 na verhoudinge wat bepaal word deur, onder meer, gemeenskaplike belydenisse en kerkregering impliseer dat gereformeerde kerke nader aan mekaar staan as ander kerke met wie daar nie eenheid in hierdie sake is nie.

Gedeeltelike verhoudinge word gelaat vir kerke met wie die NGK nie 'volle verhoudinge' het nie. Dit gaan hier om kerke van gereformeerde oortuiginge soos uitgedruk in reformatoriese belydenisskrifte. 'n Gedeeltelike verhouding veronderstel dat ' $n$ volle verhouding kan volg; dit gaan oor kerklike samewerking, 'n saampraat oor gemeenskaplike kwessies en 'n wedersydse versorging van mekaar se lidmate indien daartoe versoek. Ter wille van sy eie inligting met die oog op vordering in ekumeniese sake beywer die NGK hom in die derde plek vir dialoogverhoudinge met kerke. Hier gaan dit oor kerke wat nie 'noodwendig' op dieselfde belydenisgrondslag as die NGK staan nie. Daarnaas het die NGK kontakverhoudinge in die oog. Kortweg gaan dit om insidentele kontak sonder om ooreenkomste soos binne die ander verhoudinge, in die vooruitsig testel (NGKO 2002:32-34).

Behalwe dat NGKO 2002 aantoon met watter kerke die NGK in volle en dialoogverhoudinge staan, word hierdie sake in die Handelinge van die Algemene Sinode van 2002 vervat (NGK 2002:387; NGKO 2002:32-34). By die Algemene Sinode van 2011 word 'volle verhoudinge' in die notule egter vermeng met die omstrede 'bande'. Die acta gebruik die uitdrukking 'volle ekumeniese bande' (NGK 2007:109). 'n Niksseggende term waarvan die NGK, ná die groot verleentheid van die 1970's, skynbaar nog nie ontslae geraak het nie. Die lys van kerke met wie daar volle, gedeeltelike, dialoog- en kontakbetrekkinge is - en wat ná 2002 van tyd tot tyd gewysig word - word aan artikel 70 van die NGKO gekoppel en ná 2011 in die Reglement vir die Verhouding met ander Kerke en Groepe opgeneem (NGKO 2004:36, 2007:36-37, 2011:98-99, 2013:103-105). Verblydend is dat die drie kerke met wie daar in 2002 volle verhoudinge is in 2015 na 11 kerke aangroei - volle verhoudinge wat beteken dat hierdie kerke met mekaar kan begin praat oor die strukture van groter kerkeenheid.

\section{Slot}

Die NGK probeer, vanaf 1962 by sy eerste Algemene Sinode tot ná 2015, 'n kerkordelik-gereformeerde pad met sy ekumene loop. Hierdie pad word egter nie deurgaans uitgespel nie. In dié verband was die rol van NGKO 1974 in die sogenaamde ultimatumbesluit van die Algemene Sinode van daardie jaar oor verbreekte bande met die GKN kerkordelik 'n laagtepunt. Vanweë 'n onbeholpe formulering van NGKO 1974 artikel 70, wat onveranderd vanaf NGKO 1962 artikel 70 kom, was NGKO 1974 nutteloos vir die kerkregtelike vertolking van wat die NGK as 'verbreekte bande' beskou het. Ná 1994 het die prentjie van isolasie vir die ekumene van die NGK verander en is hy hartlik deur kerke wêreldwyd in ekumeniese verhoudinge verwelkom. Boonop is NGKO 1994 artikel 70 in 1998 gewysig om 'n kerkordelik meer verantwoorde pad vir die NGK in die ekumene oop te maak. 'n Pad waarop hy met groter afwagting sy verhoudinge met ander kerke, op die manier van die kerk, kon verbeter. Maar 'n pad wat ook in gemeentes geken en gebruik moet word.

\section{Erkenning Mededingende belange}

Die outeur verklaar dat hy geen finansiële of persoonlike verbintenis het met enige party wat hom nadelig kon beïnvloed in die skryf van hierdie artikel nie.

\section{Outersbydrae}

P.J.S. was die enigste outeur betrokke by die skryf van die artikel.

\section{Befondsing}

Hierdie navorsing het geen spesifieke finansiële toekenning ontvang van enige befondsingsagentskap in die openbare, kommersiële of nie-winsgewende sektore.

\section{Data beskikbaarheidsverklaring}

Data-deling is nie van toepassing op hierdie artikel nie, aangesien geen nuwe data in hierdie studie geskep of ontleed is nie.

\section{Vrywaring}

Die sienings en menings wat in hierdie artikel uitgedruk word, is dié van die outeur(s) en weerspieël nie noodwendig die amptelike beleid of posisie van enige geaffilieerde agentskap van die outeurs nie.

\section{Literatuurverwysings}

Crafford, D. \& Gous, G., 1993, Een liggaam, baie lede, Verba Vitae, Pretoria.

De Gereformeerde Kerken in Nederland (GKN), 1952-1953, Acta Generale Synode Rotterdam, s.n., s.I.

De Gereformeerde Kerken in Nederland (GKN), Argief. GKN-NGK korrespondensielêers 1974-1979.

De Gier, K., 1989, De Dordtse Kerkorde - een practische verklaring, Den Hertog, Houten.

De Jong, J., 1918, Verklaring van de Kerkenordening van de Nationale Synode van Dordrecht van 1618-1619. College-voordrachten van prof. dr. F.L. Rutgers over Gereformeerd Kerkrecht Deel IV, Libertas, Rotterdam.

Die Burger, 17 Oktober 1974.

Kock, P.d.B., 1975, Christelike wysbegeerte - Inleiding, Sacum, Bloemfontein.

Koffeman, L.J., 2009, Het goed recht van de kerk, Kok, Kampen.

Langner, D., 2007, Teen die hele wêreld vry - Koot Vorster, segsman of profeet, Griffel, Pretoria.

Meiring, P.G.J., 2008, 'Die NG Kerk en die Wêreldraad van Kerke - ses dekades van verwagting, verwydering en toenadering', NGTT 49(3 en 4), 193-205.

Nauta, D., 1971, Verklaring van de Kerkorde van de Gereformeerde Kerken in Nederland, Kok, Kampen.

Nederduitse Gereformeerde Kerk (NGK), 1957, Handelinge Raad van Kerke, s.n., s.I.

Nederduitse Gereformeerde Kerk (NGK), 1982, 1986, 1990, 1994, 1998, 2002, 2007, 2011, Handelinge van die Algemene Sinode van die Ned Geref Kerk, s.n., s.l. 
Nederduitse Gereformeerde Kerk (NGKO), 1962, Kerkorde van die Ned Geref Kerk, NG Kerk-Uitgewers, Kaapstad.

Nederduitse Gereformeerde Kerk (NGKO), 1974, Kerkorde van die Ned Geref Kerk, NG Kerkboekhandel, Pretoria.

Nederduitse Gereformeerde Kerk (NGKO), 1978, Die Kerkorde van die Ned Geref Kerk NG Kerkboekhandel van Transvaal, Pretoria.

Nederduitse Gereformeerde Kerk (NGKO), 1986, Die Kerkorde van die Ned Geref Kerk, NG Kerkboekhandel van Transvaal, Pretoria.

Nederduitse Gereformeerde Kerk (NGKO), 1990, Die Kerkorde van die Ned Geref Kerk, NG Kerkboekhandel 1988, Pretoria.

Nederduitse Gereformeerde Kerk (NGKO), 2002, Die Kerkorde van die Ned Geref Kerk, Lux Verbi.BM, Wellington.

Nederduitse Gereformeerde Kerk (NGKO), 2004, Die Kerkorde van die Ned Geref Kerk, Lux Verbi.BM. Wellington.

Nederduitse Gereformeerde Kerk (NGKO), 2007, Die Kerkorde van die Ned Geref Kerk Bybelmedia, Wellington.

Nederduitse Gereformeerde Kerk (NGKO), 2011, Die Kerkorde van die Ned Geref Kerk, s.n., s.l.

Nederduitse Gereformeerde Kerk (NGKO), 2013, Die Kerkorde van die Ned Geref Kerk, s.n., s.l.

Nederduitse Gereformeerde Kerk (NGKO), 2015, Die Kerkorde van die Ned Geref Kerk, s.n., s.l.

NG Kerk-Uitgewers, 1982, Ons glo..., NG Kerk-Uitgewers, Kaapstad.

Pont, A.D., 1981, Historiese agtergronde van ons kerklike reg, HAUM, Pretoria.

Reformed Ecumenical Synod (RES), 1984, Acts, s.n., s.l.

Reformed Ecumenical Council (REC), 1992, Acts, s.n., s.l.

Sizoo, A., s.a., Johannes Calvijn Institutie. Derde Deel, Boek IV, Meinema, Delft.

Spoelstra, B., 1989, Gereformeerde kerkreg en kerkregering, Teologiese Skool, Hammanskraal.
Strauss, P.J., 1983, 'Die Nederduitse Gereformeerde Kerk en die Gereformeerde Kerke in Nederland: betrekkinge rondom die Suid-Afrikaanse rassevraagstuk', DD-proefskrif, Departement Kerkgeskiedenis, Universiteit van Pretoria.

Strauss, P.J., 1989, 'Ekumene gestol?', in J.A. Durand en J.S. Kellerman (reds.), Diensknegte van die Koning, pp. 146-162, Pro Christo, Bloemfontein.

Strauss, P.J., 1991, 'Kerkreg en ekumene: 'n Verwaarloosde tema in die Ned Geref Kerk', in P.J. Strauss (red.), Byderwets en gereformeerd, pp. 187-200, Pro Christo, Bloemfontein.

Strauss, P.J., 1992, 'Die Ned Geref Kerk se "ultimatum" van 1974: Op kerklike wyse?', Acta Academica 24(2), 67-78.

Strauss, P.J., 2002, 'Die NG Kerk en sy ekumeniese bande', in F. du Toit, H. Hofmeyr, P. Strauss \& J. van der Merwe (reds.), Moeisame pad na vernuwing, pp. 181-241, Barnabas, Bloemfontein.

Strauss, P.J., 2004, 'Die teologiese en morele regverdiging van apartheid en 'n status confessionis. ' $n$ Vergelyking tussen die Wêreldbond van Gereformeerde Kerke en die Gereformeerde Ekumeniese Sinode se hantering van die saak', Acta Theologica die Gereformeerde Ekume
Supplementum 6, 96-121.

Strauss, P.J., 2010, Kerk en orde vandag, SUN MeDIA, Bloemfontein.

Strauss, P.J., 2013, 'Kerkwees in die branding. Die Ned Geref Kerk in algemene sinodale verband 1994-2011', Acta Theologica Supplementum 18.

Strauss, P.J., 2015, Gereformeerdes onder die Suiderkruis 1652-2011, SUN MeDIA, Bloemfontein.

Strauss, P.J., 2018, 'Wat het die Wêreldgemeenskap van Gereformeerde Kerke in 1998 en die Wêreldraad van Kerke in 2015 beweeg om die Ned Geref Kerk as volle lid terug te neem?', Acta Theologica 38(1), 115-141.

Van der Linde, G.P.L., 1983, Die Kerkorde, TG van Wyk, Pretoria.

Van der Watt, P.B., 1973, Die Loedolffsaak en die Ned Geref Kerk 1862-1962, Tafelberg, Kaapstad.

Vorster, J.D., 1960, 'Die kerkorde van die NG Kerke', Ned Geref Teologiese Tydskrif 1(4), 12-18.

Wêreldraad van Kerke (WRK), Argief, Ref 215/9.2.2.1/10. 